\title{
A Convenient Method for the Synthesis of 1,5-benzodiazepin-2-one
}

\author{
M. Rida ${ }^{\mathrm{a}}$, H. El Meslouhi ${ }^{\mathrm{a}}$, N.H. Ahabchane ${ }^{\mathrm{a}}$, B. Garrigues $^{\mathrm{b}}$, N. Es-Safi ${ }^{\mathrm{c}}$ and E.M. Essassi*,a \\ ${ }^{a}$ Laboratoire de Chimie Organique Hétérocyclique. Pôle de Compétences Pharmacochimie, Université Mohammed V, \\ Faculté des Sciences, Rabat, Morocco \\ ${ }^{b}$ Laboratoire Hétérochimie Fondamentale et Appliquée. Université Paul Sabatier. 118 Route de Narbonne, Toulouse, \\ France \\ ${ }^{c}$ Laboratoire de Chimie Organique et d'Etudes Physico-Chimiques. Pôle de Compétences Pharmacochimie. Ecole Nor- \\ male Supérieure, B.P 5118, Rabat Morocco
}

\begin{abstract}
New 3-hydroxy-1,5-benzodiazepin-2-ones were synthesized through condensation between $o$ phenylenediamines with glycidic ester. Alkylation and oxidation of some of the obtained compounds were also explored in different conditions yielding various oxidized and alkylated benzodiazepines. The structural elucidation of the synthesized compounds was achieved by MS, NMR spectroscopy and also through X-ray diffraction analysis. The glycidic ester was thus shown to be an interesting synthon in the synthesis of new 1,5-benzodiazepines used in alkylation and oxidation reactions.
\end{abstract}

Keywords: 1,5-benzodiazepines, condensation, alkylation, oxidation, X-ray diffraction.

\section{INTRODUCTION}

Benzodiazepine derivatives are important compounds family with various biological properties. They have attributed to many pharmacological activities among which are tranquilisant, antiviral, anti-inflammatory, analgesic, antipyretic and anticonvulsivant [1-12]. Benzodiazepine adducts are also considered as important precursors in the synthesis of benzimidazole, pyrazole, isoxazole and quinoxaline derivatives [13-18].

These beneficial health properties have led to several investigations on their chemical structures and have initiated a number of synthetic efforts to access 1,5-benzodiazepine derivatives $[15,19-28]$. In this work, we describe a new method for the synthesis of 3-hydroxy-1,5-benzodiazepin-2ones based on the condensation of $o$-phenylenediamines with a cis and trans ethyl 3-phenylglycidate.

\section{MATERIAL AND METHODOLOGY}

\section{Generals}

Melting points were determined on a Mettler FP 62 and are uncorrected. IR spectra were recorded on a Perkin-Elmer 1760x spectrometer. Mass spectra were recorded on a Nermag R-10-10C spectrometer in EI mode or on a Varian Mat 311A spectrometer $\mathrm{DCI} / \mathrm{NH}_{3}$ mode. NMR spectra were acquired using a Bruker AC 250 spectrometer. Chemical shifts are given in ppm using TMS as an internal standard.

*Address correspondence to this author at the Laboratoire de Chimie Organique Hétérocyclique. Pôle de Compétences Pharmacochimie, Université Mohammed V, Faculté des Sciences, Rabat, Morocco;

E-mail: emessassi@yahoo.fr
Synthesis of 3-hydroxy -4-phenyl tetrahydro-1,5benzodiazepin-2-one (4) and (5)

A mixture of o-phenylenediamine 1 or its dimethylated derivative $2(0.03$ mole $)$ and ethyl glycidate $(0.03$ mole $)$ was refluxed in $80 \mathrm{~mL}$ of xylene during 48 hours. The obtained crude mixture was left at room temperature during one night. The trans diastereoisomers $4 \mathrm{a}$ or $5 \mathrm{a}$ which precipitate were filtered under reduced pressure.

The filtrate was concentrated under reduced pressure and the residual obtained oil was chromatographed on silica gel column with a mixture of ether/chloroform (50/50) as eluent and yielding the trans $4 \mathrm{a}$ or $5 \mathrm{a}$ and the corresponding cis $4 \mathrm{~b}$ or $5 \mathrm{~b} 1,5$ - benzodiazepines with a predominance of the trans isomers.

trans 3-hydroxy -4-phenyl tetrahydro-1,5-benzodiazepin-2one (4a)

Yield $(\%)=85 \% ; \mathrm{F}=166-168^{\circ} \mathrm{C}($ methanol)

MS (I.E): $m / z=254\left(\mathrm{M}^{\bullet+}\right)$

${ }^{1} \mathrm{H}$ NMR (DMSOd $\left.6, \mathrm{ppm}\right): \delta: 4.15(\mathrm{dd}, 1 \mathrm{H}, \mathrm{C} 3 \mathrm{H}, \mathrm{J}=10$ $\mathrm{Hz}$ and $6 \mathrm{~Hz}) ; 4.45(\mathrm{~d}, 1 \mathrm{H}, \mathrm{C} 4 \mathrm{H}, \mathrm{J}=10 \mathrm{~Hz}) ; 4.95(\mathrm{~d}, 1 \mathrm{H}, \mathrm{OH}$, $\mathrm{J}=6 \mathrm{~Hz}) ; 5.60(\mathrm{~s}, 1 \mathrm{H}, \mathrm{NH}) ; 6.80-7.45$ (m, $9 \mathrm{H}$, Harom); 9.95 (s, $1 \mathrm{H}, \mathrm{NH})$.

${ }^{13} \mathrm{C}$ NMR (DMSOd 6 , ppm): $\delta: 70.04(\mathrm{CH}) ; 70.31(\mathrm{CH}) ;$ 122.63 (CHarom); 123.48 (CHarom); 124.32 (CHarom); 126.90 (Cq); 127.45 (CHarom); 129.11 (CHarom); 135.43 $(\mathrm{Cq}) ; 139.83(\mathrm{Cq}) ; 173.78(\mathrm{C}=\mathrm{O})$.

cis 3-hydroxy -4-phenyl tetrahydro-1,5-benzodiazepin-2one (4b)

$$
\begin{aligned}
& \text { Yield }(\%)=15 \% ; \mathrm{F}=190-192{ }^{\circ} \mathrm{C}(\text { methanol }) \\
& \text { MS (I.E): } m / z=254\left(\mathrm{M}^{\bullet+}\right)
\end{aligned}
$$




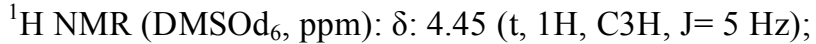
$4.60(\mathrm{~d}, 1 \mathrm{H}, \mathrm{OH}, \mathrm{J}=5 \mathrm{~Hz}) ; 4.90(\mathrm{dd}, 1 \mathrm{H}, \mathrm{C} 4 \mathrm{H}, \mathrm{J}=5$ and 6 $\mathrm{Hz})$; 6.40 (d, 1H, NH, J=6 Hz); 6.40-7.40 (m, $9 \mathrm{H}$, Harom); 9.95 (s, 1H, NH).

trans 3-hydroxy-7,8-dimethyl-4-phenyl tetrahydro-1,5benzodiazepin-2-one (5a)

Yield $(\%)=90 \% ; \mathrm{F}=236-238^{\circ} \mathrm{C}($ methanol $)$

MS (I.E): $m / z=282\left(\mathrm{M}^{*+}\right)$

${ }^{1} \mathrm{H}$ NMR (DMSOd 6 , ppm): $\delta: 2.15\left(\mathrm{~s}, 6 \mathrm{H}, 2 \mathrm{CH}_{3}\right) ; 4.08$ $(\mathrm{dd}, 1 \mathrm{H}, \mathrm{C} 3 \mathrm{H}, \mathrm{J}=10$ and $6 \mathrm{~Hz}) ; 4.40(\mathrm{~d}, 1 \mathrm{H}, \mathrm{C} 4 \mathrm{H}, \mathrm{J}=10$ $\mathrm{Hz}) ; 4.85$ (d, 1H, OH, J=6 Hz); 5.25 (s, 1 H, NH); 9.85 (s, 1 $\mathrm{H}, \mathrm{NH})$; 6.75 (s, $2 \mathrm{H}$, Harom); 7.25-7.40 (m, 5 H, Harom).

${ }^{13} \mathrm{C}$ NMR $\left(\mathrm{DMSOd}_{6}, \mathrm{ppm}\right): \delta: 19.22\left(\mathrm{CH}_{3}\right) ; 19.40\left(\mathrm{CH}_{3}\right)$; $68.13(\mathrm{CH}) ; 70.92(\mathrm{CH}) ; 125.89$ (CHarom); $126.84(\mathrm{Cq})$; 128.26 (CHarom); 129.73 (CHarom); 130.29 (Cq); 131.69 (CHarom); 139.07 (Cq); $142.59(\mathrm{Cq}) ; 172.29(\mathrm{C}=\mathrm{O})$.

cis 3-hydroxy-7,8-dimethyl-4-phenyl tetrahydro-1,5benzodiazepin-2-one (5b)

Yield $(\%)=10 \% ; \mathrm{F}=184-186{ }^{\circ} \mathrm{C}($ methanol $)$

MS (I.E): $m / z=282\left(\mathrm{M}^{*+}\right)$

${ }^{1} \mathrm{H}$ NMR (DMSOd $\left.6, \mathrm{ppm}\right): \delta: 2.05\left(\mathrm{~s}, 3 \mathrm{H}, \mathrm{CH}_{3}\right) ; 2.10(\mathrm{~s}$, $\left.3 \mathrm{H}, \mathrm{CH}_{3}\right) ; 4.40(\mathrm{t}, 1 \mathrm{H}, \mathrm{C} 3 \mathrm{H}, \mathrm{J}=5 \mathrm{~Hz}) ; 4.85(\mathrm{dd}, 1 \mathrm{H}, \mathrm{C} 4 \mathrm{H}$, $\mathrm{J}=6$ and $5 \mathrm{~Hz}) ; 4.50(\mathrm{~d}, 1 \mathrm{H}, \mathrm{OH}, \mathrm{J}=5 \mathrm{~Hz}) ; 6.10(\mathrm{~d}, 1 \mathrm{H}, \mathrm{NH}$, $\mathrm{J}=6 \mathrm{~Hz}) ; 9.80(\mathrm{~s}, 1 \mathrm{H}, \mathrm{NH}) ; 6.75$ (s, 2H, Harom); 7.20-7.40 (m, 5H, Harom).

\section{Synthesis of Compounds (9) and (10)}

To a 0,02 mole of compound $5 \mathrm{a}$ in benzol $(15 \mathrm{~mL})$ were added $5 \mathrm{~mL}$ of $50 \% \mathrm{NaOH}$ solution and ethyl bromide $(0,0022$ mole $)$ in presence of triethylbenzylammonium chloride. The mixture was stirred at $70{ }^{\circ} \mathrm{C}$ during 2 hours and extracted with methylene chloride. The organic layer was washed with water and dried with magnesium sulphate. The solvent was evaporated under reduced pressure and the obtained oil was treated with ether and the solid obtained was recristallized in methanol.

3-hydroxy-1-ethyl-7,8-dimethyl-4-phenyl tetrahydro-1,5benzodiazepin-2-one (9)

Yield $\%=70 \% ; \mathrm{F}=153-155^{\circ} \mathrm{C}$ (methanol)

MS (I.E): $m / z=310\left(\mathrm{M}^{*+}\right)$

${ }^{1} \mathrm{H} \mathrm{NMR}\left(\mathrm{CDCl}_{3}, \mathrm{ppm}\right): \delta: 1.21\left(\mathrm{t}, 3 \mathrm{H}, \mathrm{CH}_{3}, \mathrm{~J}=7 \mathrm{~Hz}\right)$; $2.22\left(\mathrm{~s}, 3 \mathrm{H}, \mathrm{CH}_{3}\right) ; 2.25\left(\mathrm{~s}, 3 \mathrm{H}, \mathrm{CH}_{3}\right) ; 3,40($ broad s, 1H, OH); $3.75(\mathrm{~d}, 1 \mathrm{H}, \mathrm{C} 3 \mathrm{H}, \mathrm{J}=10 \mathrm{~Hz}) ; 4.01\left(\mathrm{q}, 2 \mathrm{H}, \mathrm{CH}_{2}, \mathrm{~J}=7 \mathrm{~Hz}\right)$; $4.27(\mathrm{~d}, 1 \mathrm{H}, \mathrm{C} 4 \mathrm{H}, \mathrm{J}=10 \mathrm{~Hz}) ; 4,32($ broad s, $1 \mathrm{H}, \mathrm{NH}) ; 6.60$ (s, 1H, Harom); 6.99 (s, 1H, Harom); 7.25-7.36 (m, 5H, Harom).

${ }^{13} \mathrm{C} \mathrm{NMR}\left(\mathrm{CDCl}_{3}, \mathrm{ppm}\right): \delta: 13.35\left(\mathrm{CH}_{3}\right) ; 19.29\left(\mathrm{CH}_{3}\right)$; $19.49\left(\mathrm{CH}_{3}\right) ; 44.29\left(\mathrm{CH}_{2}\right) ; 70.35(\mathrm{CH}) ; 71.38(\mathrm{CH}) ; 123.49$ (CHarom); 124.44 (CHarom); 126.99 (CHarom); 128.19 (CHarom); 128.88 (CHarom); $129.47(\mathrm{Cq}) ; 131.32(\mathrm{Cq})$; $135.83(\mathrm{Cq}) ; 137.55(\mathrm{Cq}) ; 143.42(\mathrm{Cq}) ; 171.78(\mathrm{C}=\mathrm{O})$.

3-hydroxy-1-benzyl-7,8-dimethyl-4-phenyl tetrahydro-1,5benzodiazepin-2-one (10)

Yield $\%=85 \% ; \mathrm{F}=162-164{ }^{\circ} \mathrm{C}$ (methanol)

MS (I.E): $m / z=344\left(\mathrm{M}^{*+}\right)$
${ }^{1} \mathrm{H}$ NMR $\left(\mathrm{CDCl}_{3}, \mathrm{ppm}\right): \delta: 4.85\left(\mathrm{~s}, 2 \mathrm{H}, \mathrm{CH}_{2}\right) ; 5.12(\mathrm{~d}$, $\left.1 \mathrm{H}, \mathrm{C}_{3} \mathrm{H}, \mathrm{J}=10 \mathrm{~Hz}\right) ; 4.88\left(\mathrm{~d}, 1 \mathrm{H}, \mathrm{C}_{4} \mathrm{H}, \mathrm{J}=10 \mathrm{~Hz}\right) ; 7.16-7.39$ (m, 14H, Harom).

${ }^{13} \mathrm{C} \mathrm{NMR}\left(\mathrm{CDCl}_{3}, \mathrm{ppm}\right): \delta: 53.74\left(\mathrm{CH}_{2}\right) ; 70.25(\mathrm{C} 3 \mathrm{H})$; $68.74(\mathrm{C} 4 \mathrm{H}) ; 124.68 ; 125.62 ; 126.99 ; 127.18 ; 128.32$; $128.34 ; 128.85 ; 129.22 ; 129.38 ; 129.57$ (CHarom); 127.40 $(\mathrm{Cq}) ; 132.01(\mathrm{Cq}) ; 135.39(\mathrm{Cq}) ; 135.72(\mathrm{Cq}) ; 171.78(\mathrm{C}=\mathrm{O})$.

\section{Synthesis of Compounds (11) and (12)}

The same procedure indicated above was used but with a large excess of the alkylant agent and the mixture was heated at $70^{\circ} \mathrm{C}$ during 48 hours.

\section{3-ethoxy-1-ethyl-7,8-dimethyl-4-phenyl tetrahydro-1,5- benzodiazepin-2-one (11)}

Yield $(\%)=65 \% ; \mathrm{F}=156-158{ }^{\circ} \mathrm{C}($ methanol $)$

MS (I.E): $m / z=338\left(\mathrm{M}^{\bullet+}\right)$

${ }^{1} \mathrm{H}$ NMR $\left(\mathrm{CDCl}_{3}, \mathrm{ppm}\right): \delta: 0.89\left(\mathrm{t}, 3 \mathrm{H}, \mathrm{CH}_{3}, \mathrm{~J}=7 \mathrm{~Hz}\right)$; $1.17\left(\mathrm{t}, 3 \mathrm{H}, \mathrm{CH}_{3}, \mathrm{~J}=7 \mathrm{~Hz}\right) ; 2.20\left(\mathrm{~s}, 3 \mathrm{H}, \mathrm{CH}_{3}\right) ; 2.25(\mathrm{~s}, 3 \mathrm{H}$, $\left.\mathrm{CH}_{3}\right) ; 3.24\left(\mathrm{~m}, 2 \mathrm{H}, \mathrm{CH}_{2}\right) ; 3.88\left(\mathrm{~m}, 2 \mathrm{H}, \mathrm{CH}_{2}\right) ; 4.10(\mathrm{~d}, 1 \mathrm{H}$, $\left.\mathrm{C}_{3} \mathrm{H}, \mathrm{J}=10 \mathrm{~Hz}\right) ; 4.20(\mathrm{~s}, 1 \mathrm{H}, \mathrm{NH}) ; 4.63(\mathrm{~d}, 1 \mathrm{H}, \mathrm{C} 4 \mathrm{H}, \mathrm{J}=10$ $\mathrm{Hz}) ; 6.56$ (s, 1H, Harom); 6.99 (s, 1H, Harom); 7.25-7.32 (m, 5H, Harom).

${ }^{13} \mathrm{C}$ NMR $\left(\mathrm{CDCl}_{3}, \mathrm{ppm}\right): \delta: 13.29\left(\mathrm{CH}_{3}\right) ; 14.82\left(\mathrm{CH}_{3}\right)$; $19.34\left(\mathrm{CH}_{3}\right) ; 19.43\left(\mathrm{CH}_{3}\right) ; 44.08\left(\mathrm{CH}_{2}\right) ; 66.10\left(\mathrm{CH}_{2}\right) ; 70.05$ $(\mathrm{CH}) ; 71.10(\mathrm{CH}) ; 124.00$ (CHarom); 124.24 (CHarom); 126.93 (CHarom); 127.87 (CHarom); 128.87 (CHarom); $131.62(\mathrm{Cq}) ; 134.94(\mathrm{Cq}) ; 137.76(\mathrm{Cq}) ; 142.57(\mathrm{Cq}) ; 170.20$ $(\mathrm{C}=\mathrm{O})$.

3-benzyloxy-1-benzyl-7,8-dimethyl-4-phenyl tetrahydro-1,5-benzodiazepin-2-one (12)

Yield $(\%)=75 \% ; \mathrm{F}=170-172{ }^{\circ} \mathrm{C}($ methanol $)$

MS (I.E): $m / z=434\left(\mathrm{M}^{\bullet+}\right)$

${ }^{1} \mathrm{H} \mathrm{NMR}\left(\mathrm{CDCl}_{3}, \mathrm{ppm}\right): \delta: 5.26(\mathrm{~d}, 1 \mathrm{H}, \mathrm{C} 3 \mathrm{H}, \mathrm{J}=10 \mathrm{~Hz})$; $5.19(\mathrm{~d}, 1 \mathrm{H}, \mathrm{C} 4 \mathrm{H}, \mathrm{J}=10 \mathrm{~Hz}) ; 3.78\left(\mathrm{~s}, 2 \mathrm{H}, \mathrm{CH}_{2}-\mathrm{N}\right) ; 4.51(\mathrm{~s}$, $\left.2 \mathrm{H}, \mathrm{CH}_{2}-\mathrm{O}\right) ; 6.81-7.31(\mathrm{~m}, 19 \mathrm{H}$, Harom $)$.

${ }^{13} \mathrm{C}$ NMR $\left(\mathrm{CDCl}_{3}, \mathrm{ppm}\right): \delta: 51.30\left(\mathrm{CH}_{2}-\mathrm{N}\right) ; 61.68\left(\mathrm{CH}_{2}-\right.$ $\mathrm{O}) ; 70.86(\mathrm{C} 3 \mathrm{H}) ; 70.15(\mathrm{C} 4 \mathrm{H}) ; 124.68 ; 125.62 ; 126.99$; $127.18 ; 128.32 ; 128.34 ; 128.85 ; 129.22 ; 129.38 ; 129.57$ (CHarom); $127.40(\mathrm{Cq}) ; 132.01(\mathrm{Cq}) ; 135.39(\mathrm{Cq}) ; 135.72$ $(\mathrm{Cq}) ; 171.78(\mathrm{C}=\mathrm{O})$.

Synthesis of 3-(2-amino-4,5-dichloroanilino)-2-hydroxy-3phenyl ethyl propanoate (7)

A mixture of 2,4-dichloro-phenylene $6(0,03$ mole) and ethyl glycidate $3(0,03$ mole) was refluxed in xylen during 24 hours. The obtained crude mixture was left at room temperature during one night. The formed solid was filtrated and recristallized in methanol.

Yield $(\%)=60 \% ; \mathrm{F}=132-134{ }^{\circ} \mathrm{C}($ methanol $)$

MS (IE): $m / z=368,370,372\left(\mathrm{M}^{*+}\right)$

${ }^{1} \mathrm{H}$ NMR (DMSOd $\left.6, \mathrm{ppm}\right): \delta: 1.15\left(\mathrm{t}, 3 \mathrm{H}, \mathrm{CH}_{3}, \mathrm{~J}=7 \mathrm{~Hz}\right)$; 4.07 (q, 2H, $\left.\mathrm{CH}_{2}, \mathrm{~J}=7 \mathrm{~Hz}\right) ; 4.37(\mathrm{t}, 1 \mathrm{H}, \mathrm{CH}, \mathrm{J}=6.2 \mathrm{~Hz}) ; 4.63$ $(\mathrm{dd}, 1 \mathrm{H}, \mathrm{CH}, \mathrm{J}=9 \mathrm{~Hz}) ; 5.89$ (d, OH, J=6.2 Hz); 5.37 (d, 1H, $\mathrm{NH}, \mathrm{J}=9 \mathrm{~Hz}) ; 5.10\left(\mathrm{~s}, 2 \mathrm{H}, \mathrm{NH}_{2}\right) ; 6.37$ (s, 1H, Harom); 6.70 (s, 1Harom); 7.22-7.43 (m, 5H, Harom). 
${ }^{13} \mathrm{C}$ NMR (DMSOd 6 , ppm): $\delta: 13.89\left(\mathrm{CH}_{3}\right) ; 59.15(\mathrm{CH})$; $60.18 \quad\left(\mathrm{CH}_{2}\right) ; 73.45 \quad(\mathrm{CH}) ; 112.02 \quad$ (CHarom; 114.27 (CHarom); $117.52(\mathrm{Cq}) ; 118.13(\mathrm{Cq}) ; 127.17$ (CHarom); 127.81 (CHarom); 127.87 (CHarom); 134.31 (Cq); 136.55 $(\mathrm{Cq}) ; 139.08(\mathrm{Cq}) ; 171.99(\mathrm{C}=\mathrm{O})$.

\section{Synthesis of 7,8-dichloro-3-hydroxy-4-phenyl tetrahydro- 1,5-benzodiazepin-2-one (8)}

The aminoester 7 (0,03 mole) was refluxed in xylene during 48 hours. The mixture was then left at room temperature and the formed solid was filtered and recristallised in methanol.

Yield $(\%)=70 \% ; \mathrm{F}=232-234{ }^{\circ} \mathrm{C}$ (methanol)

MS (I.E): $m / z=322,324,326\left(\mathrm{M}^{\bullet+}\right)$

${ }^{1} \mathrm{H}$ NMR $\left(\mathrm{DMSOd}_{6}, \mathrm{ppm}\right): \delta: 4.24(\mathrm{~d}, 1 \mathrm{H}, \mathrm{C} 3 \mathrm{H}, \mathrm{J}=8$ $\mathrm{Hz}) ; 4.57(\mathrm{dd}, 1 \mathrm{H}, \mathrm{C} 4 \mathrm{H}, \mathrm{J}=8$ and $2 \mathrm{~Hz}) ; 5.21($ broad $\mathrm{s}, 1 \mathrm{H}$, $\mathrm{OH}) ; 6.06(\mathrm{~d}, 1 \mathrm{H}, \mathrm{NH}, \mathrm{J}=2 \mathrm{~Hz}) ; 9.93(\mathrm{~s}, 1 \mathrm{H}, \mathrm{NH}) ; 7.11(\mathrm{~s}$, $1 \mathrm{H}$, Harom); 7.12 (s, 1H, Harom); 7.27-7.33 (m, 5H, Harom).

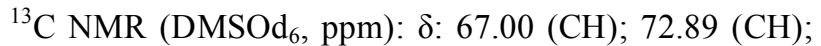
119.64 (Cq); 120.08 (CHarom); 122.27 (CHarom); 125.55 (Cq); 127.08 (CHarom); $127.31 \quad$ (CHarom); 128.07 (CHarom); $139.933(\mathrm{Cq}) ; 142.47(\mathrm{Cq}) ; 171.78(\mathrm{C}=\mathrm{O})$.

Synthesis of 3-hydroxy-1-ethyl-7,8-dimethyl-4-phenyl tetrahydro-1,5-benzodiazepin-2-one (13b)

To a 0,0015 mole of pyridinium chlorochromate in $5 \mathrm{ml}$ of dichloromethane was rapidly added a solution of 0,001 mole of 11 in $5 \mathrm{ml}$ of dichloromethane at room temperature and under nitrogen atmospher. The mixture was stirred during 1 hour and diluted with dichloromethane. The black solid was removed by filtration under vacuum and the filtrate was concentrated by evaporation under reduced pressure. The obtained residual oil was twisted in methanol yielding pure compound 13b.

Yield $(\%)=60 \% ; \mathrm{F}=112-113^{\circ} \mathrm{C}$ (methanol)

MS (IE): $m / z=336\left(\mathrm{M}^{\bullet+}\right)$

${ }^{1} \mathrm{H}$ NMR (DMSOd 6, ppm): $\delta: 0.96\left(\mathrm{t}, 3 \mathrm{H}, \mathrm{CH}_{3}, \mathrm{~J}=6.8\right.$ $\mathrm{Hz}) ; 1.01\left(\mathrm{t}, 3 \mathrm{H}, \mathrm{CH}_{3}, \mathrm{~J}=6.8 \mathrm{~Hz}\right) ; 2.29\left(\mathrm{~s}, 3 \mathrm{H}, \mathrm{CH}_{3}\right) ; 2.31(\mathrm{~s}$, $\left.3 \mathrm{H}, \mathrm{CH}_{3}\right) ; 3.37\left(\mathrm{~m}, 2 \mathrm{H}, \mathrm{CH}_{2}\right) ; 3.96\left(\mathrm{~m}, 2 \mathrm{H}, \mathrm{CH}_{2}\right) ; 4.39(\mathrm{~s}$, $1 \mathrm{H}, \mathrm{C} 3 \mathrm{H}) ; 7.21$ (s, 1H, Harom); 7.36 (s, 1H, Harom); 7.458.05 (m, 5H, Harom).

${ }^{13} \mathrm{C}$ NMR $\left(\mathrm{CDCl}_{3}, \mathrm{ppm}\right): \delta: 16.43\left(\mathrm{CH}_{3}\right) ; 17.14\left(\mathrm{CH}_{3}\right)$; $22.50\left(\mathrm{CH}_{3}\right) ; 22.87\left(\mathrm{CH}_{3}\right) ; 45.97\left(\mathrm{CH}_{2}\right) ; 68.87\left(\mathrm{CH}_{2}\right) ; 82.62$ $(\mathrm{CH}) ; 126.83$ (CHarom); 130.40 (CHarom); 131.53 (CHarom); 131.66 (CHarom); $132.77 \quad(\mathrm{Cq}) ; 133.85$ (CHarom); $134.22(\mathrm{Cq}) ; 139.27(\mathrm{Cq}) ; 139.55(\mathrm{Cq}) ; 142.62$ $(\mathrm{Cq}) ; 166.18(\mathrm{C}=\mathrm{N}) ; 168.02(\mathrm{C}=\mathrm{O})$.

\section{RESULTS AND DISCUSSION}

In an ongoing program dealing with the synthesis of new 1,5-benzodiazepin-2-ones with potent biological properties, a new method for the preparation of 3-hydroxy-1,5benzodiazepin-2-ones was investigated through the condensation of $o$-phenylenediamines with a cis and trans ethyl 3phenylglycidate. This was achieved by heating both reactants in xylen. In these conditions, a mixture of two cis and trans 3-hydroxy-4-phenyl-1,3,4,5-tetrahydro-1,5-benzodiazepin-2one $4 a, 4 b$ or $5 a, 5 b$ diastereoisomers were formed and separated through silica gel column chromatography (Scheme 1).
The obtained compounds were identified through MS and ${ }^{1} \mathrm{H}$ and ${ }^{13} \mathrm{C}$ NMR spectroscopy. The configuration of each diastereoisomer was determined from the ${ }^{1} \mathrm{H}$ NMR spectrum through the coupling constant between the 3 and 4 protons of the seven membered ring. Thus in the case of compounds $4 \mathrm{a}$ and 5a the obtained doublets showed a coupling constant of $10 \mathrm{~Hz}$ (trans) while a coupling constant of $5 \mathrm{~Hz}$ (cis) was obtained in compounds $4 \mathrm{~b}$ and $5 \mathrm{~b}$. The ${ }^{13} \mathrm{C}$ NMR spectrum showed specific signals assigned as the methylene groups appearing at $70 \mathrm{ppm}$.

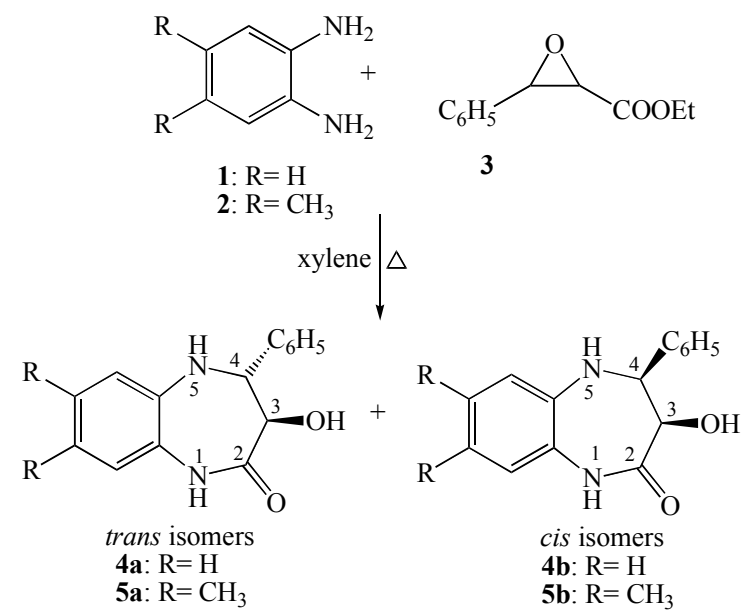

Scheme 1.

It may be noted that no intermediate has been isolated in these reactions. However, when the 4,5-dichloro ophenylenediamine 6 was refluxed during 24 hours in xylen with the cis/trans ethyl 3-phenylglycidate mixture, the aminoester ethyl 3-(2-amino-4,5-dichloroanilino)-2-hydroxy-4phenylpropanoate 7 has been isolated. When the latter was refluxed in xylen during 48 hours, the 7,8-dichloro-3hydroxy-4-phenyl-1,3,4,5-tetrahydro-1,5-benzodiazepin-2one 8 was isolated (Scheme 2), and identified through ${ }^{1} \mathrm{H}$, ${ }^{13} \mathrm{C}$ NMR and MS spectroscopy.

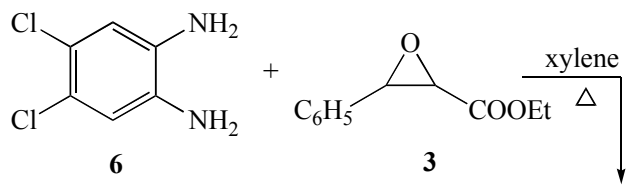

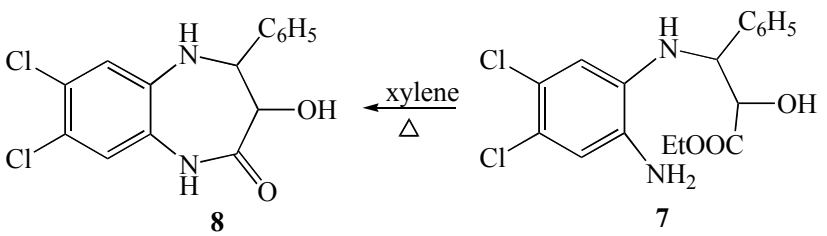

Scheme 2.

This result showed the effect of the used diamine derivative on the reaction. Thus when the dichlorinated diamine 6 was used only one diastereoisomer $\mathbf{8}$ was obtained with the aminoester $\mathbf{7}$ as intermediate.

A mechanism of formation of the synthesized benzodiazepinones 4, 5 and 8 has been proposed. The first step of this mechanism is an attack of the amino group on the position 3 carbon atom. This causes an opening of the oxirane 
ring and gives the intermediate aminoester which through the attack of the second amino group on the ester carbonyl group yield the seven membered ring.

After having synthesized the benzodiazepinones, we were interested to their alkylation by various alkylant agents. Thus the reaction of ethyl bromide and benzyl chloride on the trans 3-hydroxy-4-phenyl-1,3,4,5-tetrahydro-1,5benzodiazepin-2-one $\mathbf{4 b}$ and $\mathbf{5 b}$ was investigated. The reaction, achieved in the conditions of liquid-solid CTP conditions, showed the influence of the used amount of the alkylation agent. Thus when the substrate was heated during 2 hours with a small excess of the alkylant agent, the only alkylated site was the nitrogen in position 1 giving 1-alkyl-3hydroxy-4-phenyl-1,3,4,5-tetrahydro -1,5-benzodiazepin-2one 9 and 10. When the same reaction was conducted with a large excess of the alkylant agent during 48 hours, only one dialkylated derivative was obtained where the nitrogen in position 1 and the hydroxyl oxygen atoms were involved giving the dialkylated derivatives 11 and 12 (Scheme 3).

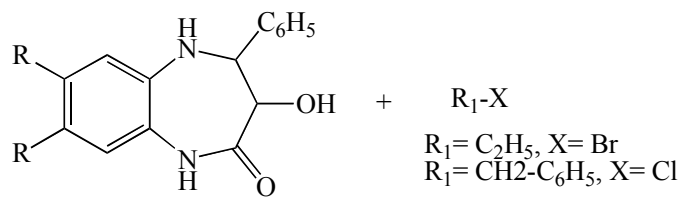

4b: $\mathrm{R}=\mathrm{H}$

5b: $\mathrm{R}=\mathrm{CH}_{3}$

$\mathrm{NaOH} 50 \%$, CETBA $\downarrow$ Benzene, $70{ }^{\circ} \mathrm{C}$<smiles>[R]OC1C(=O)N([R1])c2cc([R])c([R])cc2NC1CCCC</smiles>

9: $\mathrm{R}=\mathrm{CH}_{3}, \mathrm{R}_{1}=\mathrm{C}_{2} \mathrm{H}_{5}, \mathrm{R}_{2}=\mathrm{H}$

10: $\mathrm{R}=\mathrm{H}, \mathrm{R}_{1}=\mathrm{CH}_{2}-\mathrm{C}_{6} \mathrm{H}_{5}, \mathrm{R}_{2}=\mathrm{H}$

11: $\mathrm{R}=\mathrm{CH}_{3}, \mathrm{R}_{1}=\mathrm{R}_{2}=\mathrm{C}_{2} \mathrm{H}_{5}$

12: $\mathrm{R}=\mathrm{H}, \mathrm{R}_{1}=\mathrm{R}_{2}=\mathrm{CH}_{2}-\mathrm{C}_{6} \mathrm{H}_{5}$

Scheme 3.

It may be noted that when the same reaction was conducted in the conditions of liquid solid CTP conditions using DMF in presence of $\mathrm{K}_{2} \mathrm{CO}_{3}$ as a basis and triethylbenzylammonium chloride as catalyst, only the monoalkylated adducts 9 and 10 were obtained even with a large excess of alkylant agent. It may finally noted that during these reactions no alkylation involving the position 5 nitrogen atom was observed. The structures of the mono and dialkylated derivatives were all elucidated through ${ }^{1} \mathrm{H}$ and ${ }^{13} \mathrm{C}$ NMR spectroscopy which showed the signals corresponding the alkyl groups and were also confirmed by MS spectroscopy and X ray diffraction analysis (Figs. $\mathbf{1}$ and $\mathbf{2}$ ).

We were also interested to oxidize the 3-ethoxy-1-ethyl7,8-dimethyl-4-phenyl tetrahydro-1,5-benzadiazepin-2-one 11 in order to prepare new 1,5-benzodiazepines with potent biological properties. This was achieved through the Corey and Suggs [29] method using pyridinium chlorochromate in anhydrous dichloromethane and under nitrogen. Compound 13b was thus obtained and its structure was showed to be the 1-ethyl-3-ethoxy- -7-8-dimethyl-4-phenyl tetrahydro-1,5benzadiazepin-2-one as confirmed by its ${ }^{1} \mathrm{H},{ }^{13} \mathrm{C}$ and $\mathrm{MS}$ spectral data. Its formation with a high yield could be explained by a dehydrogenation of compound $\mathbf{1 1}$ yielding the dihydro-1,5-benzodiazepin-2-one 13 which exists in two 13a and 13b tautomeric forms. The equilibrium being largely dominated by the $\mathbf{1 3 b}$ form (Scheme 4 ).

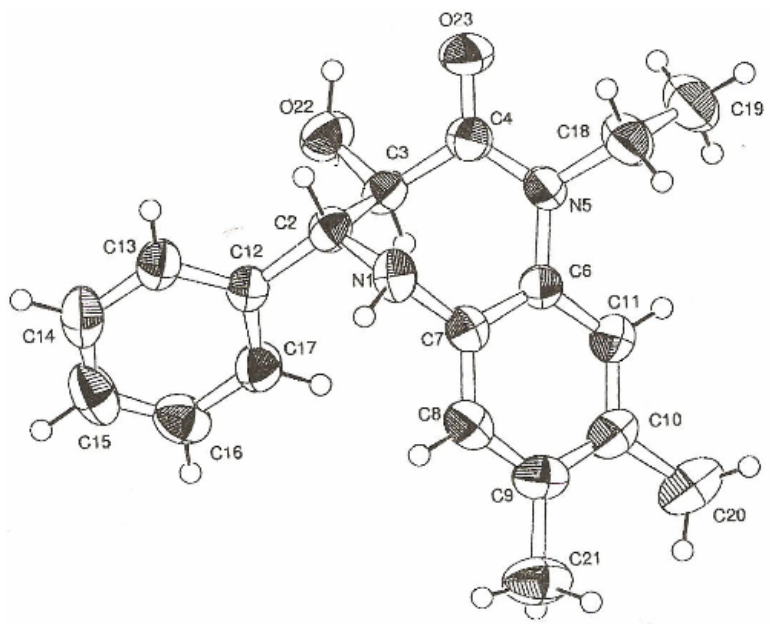

Fig. (1). ORTEP of compound 9.

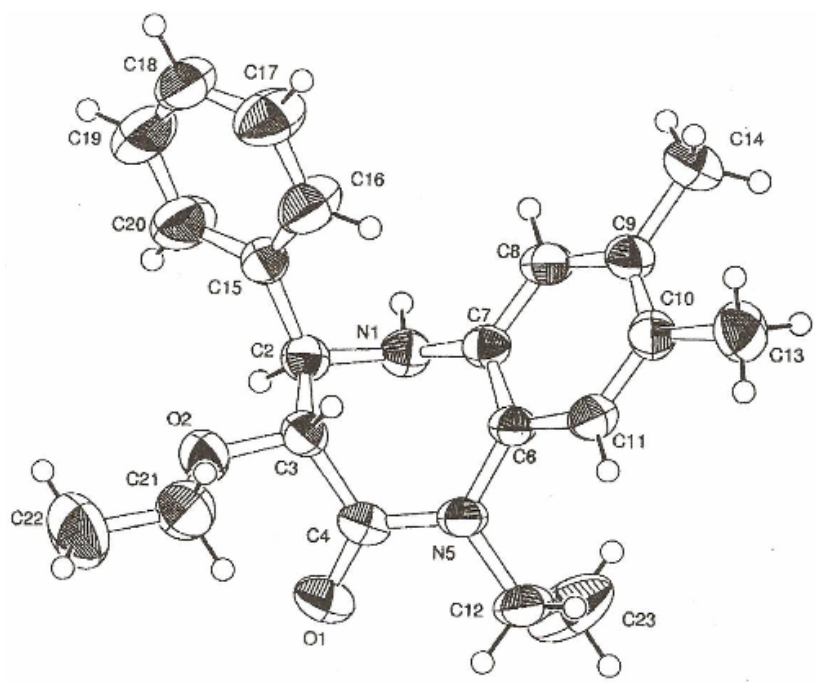

Fig. (2). ORTEP of compound 11.

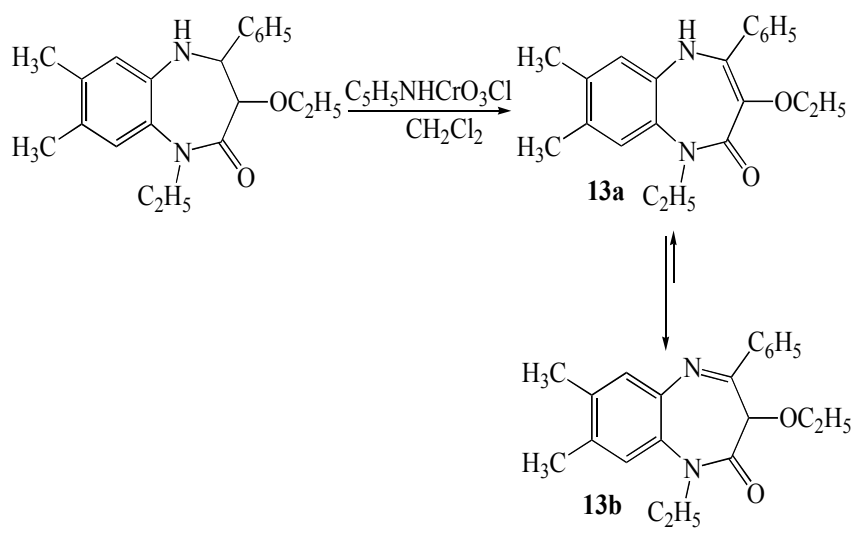

Scheme 4. 
The structure of compound $\mathbf{1 3 b}$ was elucidated through ${ }^{1} \mathrm{H}$ and ${ }^{13} \mathrm{C}$ NMR spectroscopy which results were in agreement with the proposed structure. This was also confirmed by MS spectroscopy and X ray diffraction analysis (Fig. 3 ).

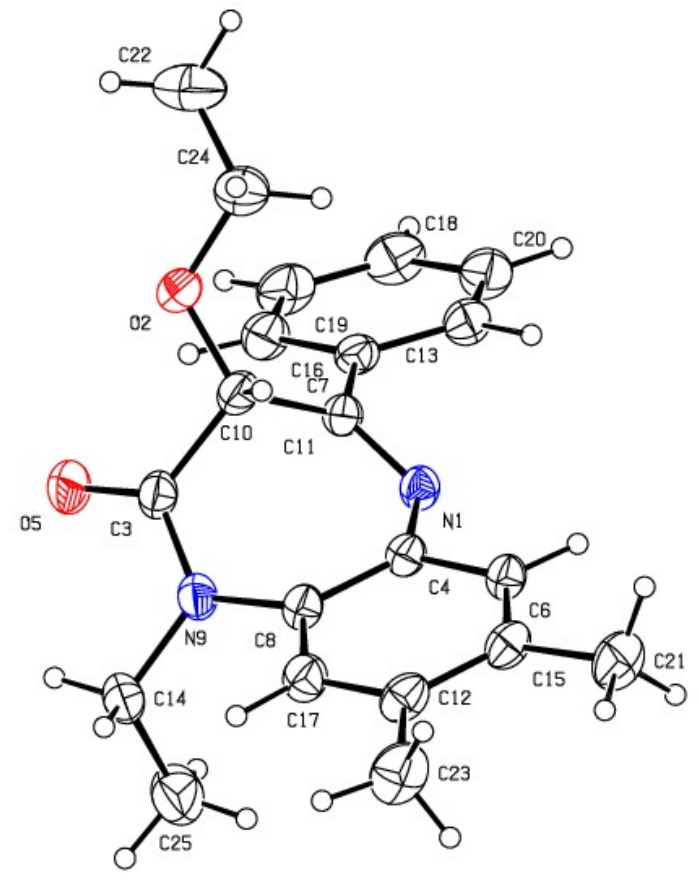

Fig. (3). ORTEP of compound $\mathbf{1 3 b}$.

\section{REFERENCES}

[1] Brambilla, G.; Carrozzino, R.; Martelli, A. Pharm. Res., 2007, 56, 443.

[2] Dourlat, J.; Liu, W.Q.; Gresh, N.; Garbay, C. Bioorg. Med. Chem. Lett., 2007, 17, 2527.

[3] Clark, R.L.; Carter, K.C.; Mullen, A.B.; Coxon, G.D.; OwusuDapaah, G.; McFarlane, E.; Duong, T.; Grant, M.H.; Tettey, J.N.A.; Mackay, S.P. Bioorg. Med. Chem. Lett., 2007, 17, 624.

[4] Gaillard, R.; Ouanas, A.; Spadone, C.; Llorca, P.-M.; Lôo, H.; Baylé, F.-J. L'Encéphale, 2006, 32, 1003.

[5] Francis, T.M.; Sundberg, T.B.; Cleary, J.; Groendyke, T.; Opipari, A.W.; Glick, G.D. Bioorg. Med. Chem. Lett., 2006, 16, 2423.
[6] Zappalà, M.; Pellicanò, A.; Micale, N.; Menniti, F.S.; Ferreri, G.; De Sarro, G.; Grasso, S.; De Micheli, C. Bioorg. Med. Chem. Lett., 2006, 16, 167.

[7] Mikkelsen, J.D.; Søderman, A.; Kiss, A.; Mirza, N. Eur. J. Pharmacol., 2005, 519, 223.

[8] Kumar, R.; Lown, J.W. Eur. J. Med. Chem., 2005, 40, 641.

[9] Di Braccio, M.; Grossi, G.; Roma, G.; Vargiu, L.; Mura, M.; Marongiu, M.E. Eur. J. Med. Chem., 2001, 36, 935.

[10] De Lucca, G.V.; Otto, M.J. Bioorg. Med. Chem. Lett., 1992, 2, 1639.

[11] Grossi, G.; Di Braccio, M.; Roma, G.; Ballabeni, V.; Tognolini, M.; Calcina, F.; Barocelli, E. Eur. J. Med. Chem., 2002, 3, 933.

[12] Narayana, B.; Vijaya Raj, K.K.; Ashalatha, B.V.; Suchetha, K.N. Eur. J. Med. Chem., 2006, 41, 417.

[13] Ahabchane, N.H.; Essassi, E.M.; Lopez, L.; Bellan, J.; Lamandé, L. C.R. Acad. Sci. Paris, Série IIc, 2000, 3, 313.

[14] Ahabchane, N.H.; Essassi, E.M.; Lopez, L.; Bellan, J.; Lamande, L. Phosphorus Sulfur Silicon, 2001, 173,175.

[15] Ahabchane, N.H.; Ibrahimi, S.; Salem, M.; Essassi, E.M; Hamzazi, S.; Benjouad, A. C. R. Acad. Sci. Paris, Série IIc, 2001, 4, 917.

[16] Ghomsi, N.T.; Ahabchane, N.H.; Essassi, E.M. Phosphorus Sulfur Silicon, 2004, 179, 353.

[17] El Azzaoui, B.; Azzaoui, B.; Bouhfid, R.; Doumbia, M.L.; Essassi, E.M.; Gornitzka, H.; Bellan, J. Tetrahedron Lett., 2006, 47, 8807.

[18] Ghomsi, N.T.; Ahabchane, N.H.; Es-Safi, N.; Garrigues, B.; Essassi, E.M. Spect. Lett., 2007, 40, 741.

[19] Essassi, E.M. Bull. Soc. Chim. Belg., 1994, 103, 694.

[20] Benchidmi, M.; Essassi, E.M.; Ferfra, S.; Fifani, J. Bull. Soc. Chim. Belg., 1993, 102, 679.

[21] Nishimura, N.; Koyano, Y.; Sugiura, M.; Maeba, I. Heterocycles, 1999, 51,803 .

[22] Essassi, E.M.; Viallefont, Ph.; Zniber, R. Bull. Soc. Chim. Fr., 1986, 797.

[23] Essassi, E.M.; El Abbassi, M.; Fifani, J. Bull. Soc. Chim. Belg., 1987, 28, 1389.

[24] Di Braccio, M.; Grossi, G.; Ceruti, M.; Rocco, F.; Loddo, R.; Sanna, G.; Busonera, B.; Murreddu, M.; Marongiu, M.E. Il Farmaco, 2005, 60, 113 .

[25] Hussenether, T.; Hübner, H.; Gmeiner, P.; Troschütz, R. Bioorg. Med. Chem., 2004, 12, 262.

[26] Fruscella, P.; Sottocorno, M.; Di Braccio, M.; Diomede, L.; Piccardi, N.; Cagnotto, A.; Grossi, G.; Romano, M.; Mennini, T.; Roma, G. Pharm. Res., 2001, 43, 445.

[27] Roma, G.; Grossi, G.C.; Di Braccio, M.; Ghia, M.; Mattioli, F. Eur. J. Med. Chem., 1991, 26, 489.

[28] Di Braccio, M.; Roma, G.; Grossi, G.C.; Ghia, M.; Mereto, E. Eur. J. Med. Chem., 1990, 25, 681 .

[29] Corey, E.J.; Suggs, W. Tetrahedron Lett., 1975, 31, 2647.

(C) Rida et al.; Licensee Bentham Open.

This is an open access article licensed under the terms of the Creative Commons Attribution Non-Commercial License (http://creativecommons.org/licenses/by-nc/3.0/) which permits unrestricted, non-commercial use, distribution and reproduction in any medium, provided the work is properly cited. 